\title{
Influence of Magnetic Field on Molten-Salt Flow
}

\author{
Kokichi TsuneKaWA*, Kazutaka KaWamurA***, Yoshio Kato***, \\ and Kazuo FURUKAWA***
}

\begin{abstract}
Emf's in the molten salt flow induced by imposed magnetic field were measured. The purpose of this work is to obtain some fundamental knowledges on a molten salt as a blanket material for controlled thermonuclear fusion reactors. The measurements were made with moblie glass-insulated platinum electrodes by traversing a circular pipe with an inside diameter of $0.054 \mathrm{~m}$. A magnetic field of 0.72 $\mathrm{T}$ was imposed at the maximum to the flow and its mean velocity was increased to $0.95 \mathrm{~m} \mathrm{~s}^{-1}$. A molten nitrate and nitrite mixture (HTS) was used as a test fluid. Consequently we obtained profiles of the emf and calculated velocity distributions of the flow, which show that little hydrodynamic effect due to the magnetic field on the flow velocity was observed on the present system.
\end{abstract}

\section{Introduction}

Molten salts have been considered as a candidate for blanket materials for controlled thermonuclear fusion reactors and especially for hybrid ones. Although other candidates, liquid lithium and its alloys, show higher breeding ratio of tritium than them, it is considered as a fault that a huge pumping power is required to pass it through intense magnetic fields ${ }^{1 \sim 3}$. In the case of molten salts the effect of the magnetic field on the flow is expected so small that the flow is little disturbed, but, on the other hand, we do not know to what extent the induced emf enhances corrosion of conduits ${ }^{4}$. It is the purpose of this paper to measure the induced emf and to investigate the influence of imposed magnetic field on molten-salt flow by using the emf.

\section{Emf Caused by MHD Effect}

Emf induced in a flowing electroconductive fluid under magnetic field has been investigated as a problem of magnetohydrodynamics ${ }^{5 \sim 9}$. Molten salts as such a fluid are first characterized by their intermediate specific conductivity between aqueous solutions and liquid metals, which is reflected by the Hartmann number. $\mathrm{Hy}^{-}$ drodynamic effect of magnetic fields on a flow is scaled by a ratio of the Hartmann number to the

* Research Laboratory for Nuclear Reactors, Tokyo Institute of Technology (2-12-1, Ookayama,Meguroku, Tokyo 152)

** Institute of Plasma Physics, Nagoya University (Furo-cho, Chikusa-ku, Nagoya 464)

*** Japan Atomic Energy Research Institute (Tokai-mura, Naka-gun, Ibaraki-ken 319-11)

Key Words: Molten Salt, Blanket, Fusion Reactor, Magnetic Field, Induced Potential
Reynolds number or by the Stuart number. To examine the effect on the present system in advance we calculated such dimensionless numbers as shown in Table 1 from the published physicochemical constants of the salt used in this system ${ }^{10 \sim 12)}$, where $\mathrm{Ha}, \mathrm{Re}$ and $\mathrm{N}$ represent the Hartmann number, Reynolds number and Stuart number, respectively. Foregoing workers ${ }^{13)}$ pointed out that

Table 1 Operating conditions expressed by dimensionless numbers at $490 \mathrm{~K}$

\begin{tabular}{|c|c|c|c|c|}
\hline$V_{\mathrm{m}} / \mathrm{m} \mathrm{s}^{-1} B / \mathbf{T}$ & $\mathrm{Ha}$ & $\operatorname{Re}$ & $\mathrm{Ha} / \mathrm{Re}$ & $\mathrm{N}$ \\
\hline $0.95, \quad 0.721$ & 1.96 & $2.16 \times 10^{4}$ & $9.08 \times 10^{-5}$ & $1.78 \times 10^{-4}$ \\
\hline $0.95,0.566$ & 1.54 & $2.16 \times 10^{4}$ & $7.13 \times 10^{-5}$ & $1.10 \times 10^{-4}$ \\
\hline $0.63,0.721$ & 1.96 & $1.44 \times 10^{4}$ & $1.37 \times 10^{-4}$ & $2.68 \times 10^{-4}$ \\
\hline $0.63, \quad 0.566$ & 1.54 & $1.44 \times 10^{4}$ & $1.07 \times 10^{-4}$ & $1.64 \times 10^{-4}$ \\
\hline $0.32, \quad 0.721$ & 1.96 & $7.19 \times 10^{3}$ & $2.72 \times 10^{-4}$ & $5.34 \times 10^{-4}$ \\
\hline $0.32, \quad 0.566$ & 1.54 & $7.19 \times 10^{3}$ & $2.14 \times 10^{-4}$ & $3.29 \times 10^{-4}$ \\
\hline $0.32, \quad 0.201$ & 0.55 & $7.19 \times 10^{3}$ & $7.59 \times 10^{-5}$ & $1.53 \times 10^{-5}$ \\
\hline
\end{tabular}

such a flow is affected by magnetic field when the Stuart number $\mathrm{N}$ exceeds $10^{-3}$. According to Table 1 the values of $\mathrm{N}$ are slightly smaller than $10^{-3}$, so that this system was expected to be operated under the boundary region. Another problem to be considered in this system is that contact resistance or in other words polarization resistance between the salt and the metal wall can be never neglected in contrast with liquid metal-metal wall systems ${ }^{16)}$. Shercliff analyzed such a Poiseuille flow with contact resistance ${ }^{9}$. On the basis of axisymmetry utilizing his analysis we derived an equation which expresses potential distribution $U(r)$ in the interior of the Poiseuille flow as follows : 


$$
\begin{aligned}
U(r) & =\frac{B r}{2}\{\bar{V}(r) \\
& \left.+V_{\mathrm{m}} \frac{\frac{a}{D}+\lambda\left(1-\frac{a}{D}\right) \frac{b^{2}-a^{2}}{a^{2}+b^{2}}}{\frac{a}{D}+\lambda\left(1+-\frac{a}{D}\right) \frac{b^{2}-a^{2}}{a^{2}+b^{2}}}\right\},
\end{aligned}
$$

where $r$ is the distance perpendicular to the magnetic field from the center of the flow. $B, a$ and $b$ are the magnetic flux density imposed perpendicular to the flow, inside radius of the pipe and outside one, respectively. $\bar{V}(r)$ is the flow velocity averaged over the circular section with radius $r . V_{\mathrm{m}}, \lambda$ and $D$ are defined by;

$$
\begin{aligned}
& V_{\mathrm{m}} \equiv \bar{V}(a), \\
& \lambda \equiv \frac{\kappa_{\mathrm{W}}}{\kappa_{\mathrm{F}}},
\end{aligned}
$$

and

$$
D \equiv \frac{\kappa_{\mathrm{F}}}{\tau},
$$

where $\kappa_{\mathrm{W}}$ and $\kappa_{\mathrm{F}}$ are the specific conductivity of the wall and that of the fluid. $\tau$ denotest he interfacial conductivity between the wall and the fluid.

\section{Measurement of Induced Potentials}

Figure 1 shows a bird's-eye view of the forced convection loop used in this work. It is made of SUS 316 and the in-situ test section is connected by Grayloc fittings to avoid leakage at elevated temperatures. The loop is only fixed at the pump on the floor and the other parts are supported by rollers preventing the disruption due to thermal expansion. Sheathed heaters are wound on the pipe and they are covered with rock wool with thickness of about $60 \mathrm{~mm}$. The temperature of the loop is controlled within $1^{\circ} \mathrm{C}$ by a PID controller.

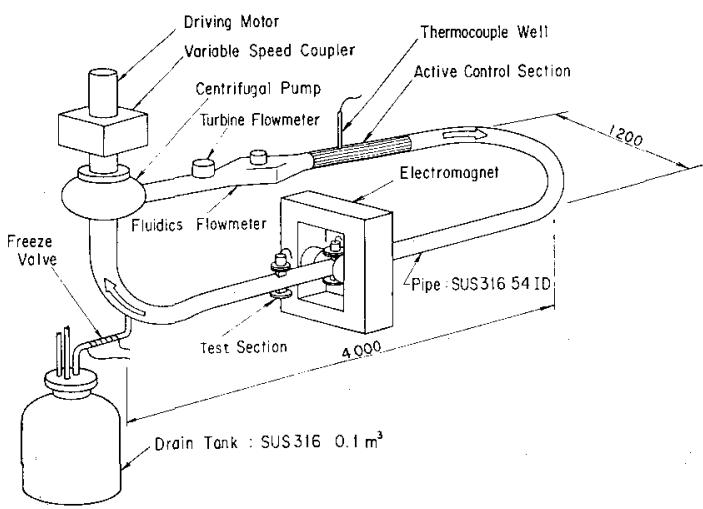

Fig. 1 Forced convection loop for molten salt
Purified nitrogen is supplied to the loop as a cover gas during operation. The molten salt used in this work is a ternary mixture of sodium and potassium nitrates and a nitrite $(49 \mathrm{~mol}$ \% $\mathrm{NaNO}_{2}, 44 \mathrm{~mol} \% \mathrm{KNO}_{3}$ and 7 mol$\% \mathrm{NaNO}_{3}$ ) which is generally known as a heat transfer medium HTS. The salt is transferred by nitrogen pressure from the drain tank through the freeze valve and the valve is freezed after the loop is completely filled.

A free surface of the salt is left in the pump bowl to avoid thermal stress and its level is detected by four contact type level indicators. The salt is circulated by the pump with capacity of $3.3 \times 10^{-3} \mathrm{~m}^{3} \mathrm{~s}^{-1}$, which is driven through the variable speed coupler that varies and maintains its rotational speed. The loop is equipped with flowmeters of two different types. One is a fluidics flowmeter to which self excited oscillation of a fluid circuit with positive feedback is applied and the other is a conventional turbine flowmeter. Both the flowmeters were otherwise calibrated with water and the molten salt used in this work. Consequently it became clear that the latter keeps its accuracy of two percents for the molten salt compared with the case of water. The test section is placed so as to make the flow less disturbed and better developed. The electromagnet generates magnetic flux density up to $1 \mathrm{~T}$ and is able to travel along the pipe over the same range as the tset section. Figure 2 shows a cutaway view of the test section. The probes, which have the same dimensions, are made of Pyrex glass and have a platinum electrode.

Each probe is fixed by a neoplene $o$-ring to the ball-nut screw which enables it to traverse the pipe and the other $o$-ring made of teflon makes the loop gas tight with freedom of slide. The platinum electrodes, sticking forward $22 \mathrm{~mm}$, have a diameter of $1.5 \mathrm{~mm}$. As shown in Fig. 2 a potential difference between the electrodes is led to the electrometer (HA-301, Hokuto Denko Ltd.), input impedance of which is at least $10^{11} \Omega$, which is large enough to neglect itself compared with polarization resistance of the probes magnitude of which is $10^{6} \Omega$. Measurements are carried out by intermittently imposing magnetic flux on the flow. Accordingly induced potentials are recorded as differences 


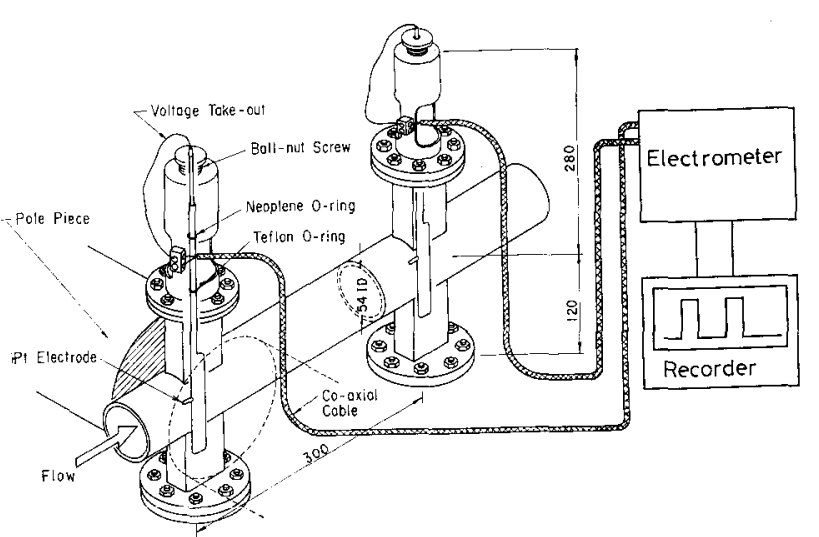

Fig. 2 Cutaway view of the test section for emf measurement and measuring setup

from the base line.

\section{Results and Discussion}

Before achieving the measurements we briefly examined some phenomena which may cause errors. First, it became clear that transient of the emf which may make it difficult to read the output does not continue so long as it disturbes our reading.

Using one of the two electrodes as a reference electrode, we hardly know to what extent the magnetic field at the reference electrode may cause an error. As a result of the measurements on

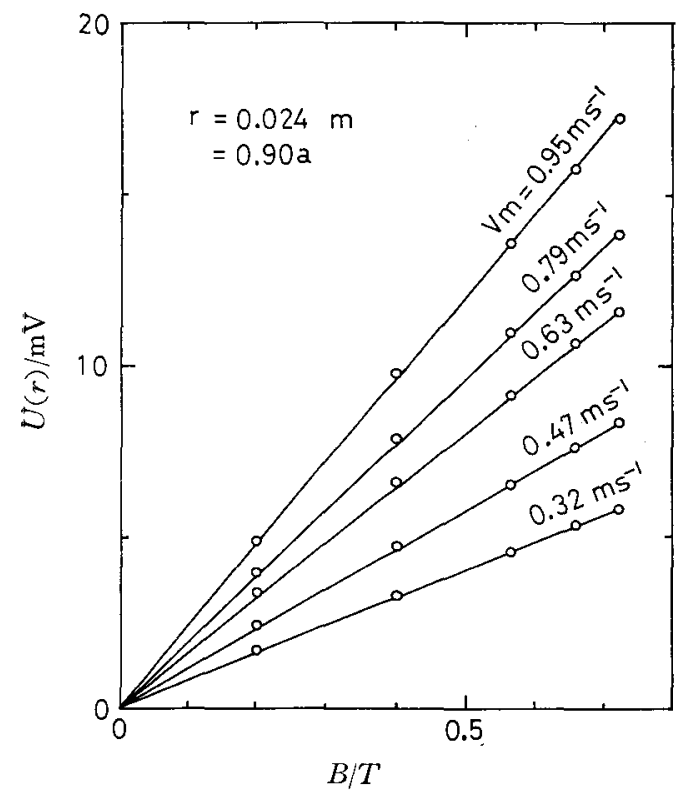

Fig. 3 Dependence of emf on the magnetic flux density at $r=26 \mathrm{~mm}$ the magnetic flux distribution it became clear that the magnetic flux density at the reference electrode is about $4 \%$ of that measured at the center of the pole pieces. Accordingly when the reference electrode is located within $10 \%$ of the inside radius from the center the influence is estimated to be less than $0.4 \%$. Edge effect for the induced potential profile was not observed. It seems that no edge effect observed is due to the small Hartmann number. Having completed these preparatory examinations, we obtained the induced potentials depending on the magnetic flux density, flow rate and position of the electrode. Figure 3 shows that induced emf's increase proportionally as the imposed magnetic field increases. This means a little effect of magnetic field on the mean velocity under the condition in this work.

Flow-rate dependence of the induced emf's is shown in Fig. 4. Potentials observed at $90 \%$

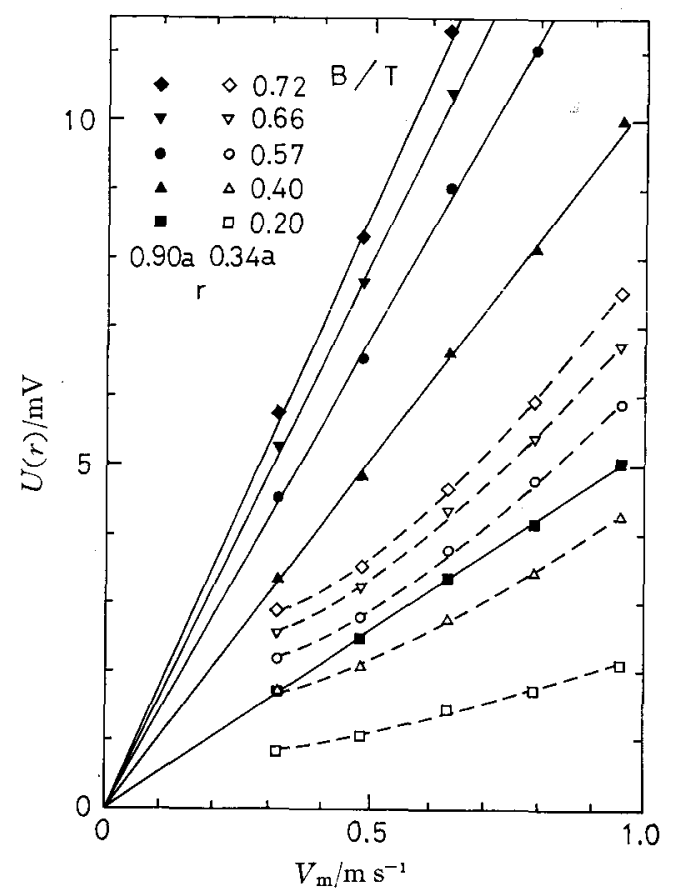

Fig. 4 Relation between the mean velocity of the flow $V_{\mathrm{m}}$ and the potentials $U(r)$ induced at different radii, which are plotted by regarding the imposed magnetic flux desity $B$ as a parameter, where ' $a$ ' denotes the inside radius of the pipe 


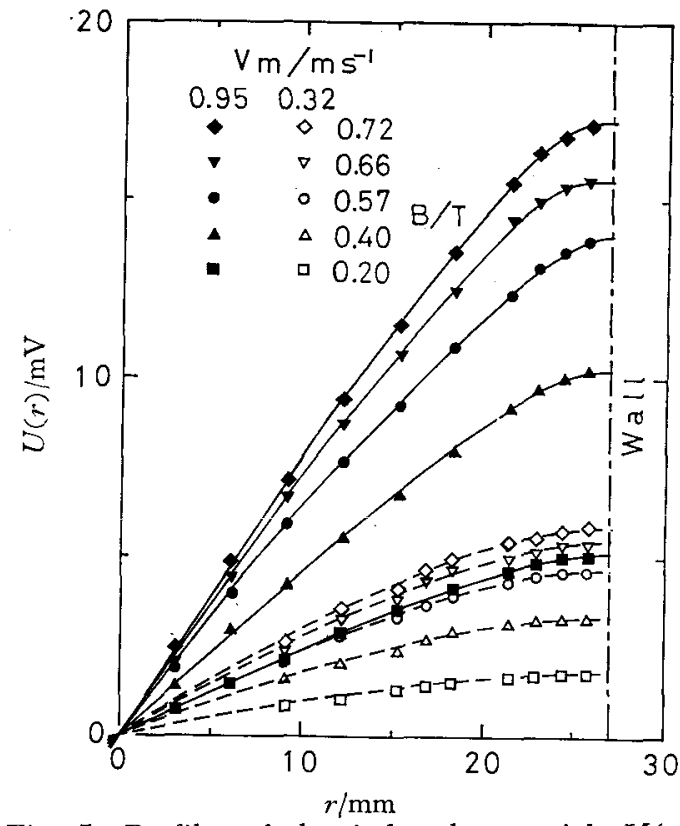

Fig. 5 Profiles of the induced potentials $U(r)$ along the radius $r$ perpendicular to the magnetic flux at different mean velocities $V_{\mathrm{m}}$ of the flow, which are plotted by regarding the magnetic flux density $B$ as a parameter

of the inside radius appear distributed closely around the straight lines containing the origin, while on the other hand those observed at $34 \%$ of the radius seem to be strayed from the straight lines mainly at low flow-rate range. It suggests that the velocity profile varies with decrease of the flow rate. Induced potentials in the interior of the flow are plotted in Fig. 5. This figure also suggests that the curves deviates far from straight lines near the wall in the case of low flow rate. When velocity profiles are given, induced potentials can be estimated by using equation (1). Induced emf's for the Hagen-Poiseuille flow (parabolic profile), those for the uniform flow (rectangular profile) and observed values are plotted together against the mean velocity and Reynolds number in Fig. 6. According to this figure it can be seen that the induced potentiais approach those for the HagenPoiseuille flow as the mean velocity decrease. Based on this we calculated velocity profiles from the induced emf's. An equation which expresses $V(r)$ is derived from equation (1) :

$$
\begin{aligned}
V(r) & =\frac{1}{B}\left\{\frac{U(r)}{r}+U^{\prime}(r)\right\} \\
& -V_{\mathrm{m}} \frac{\frac{a}{D}+\lambda\left(1-\frac{a}{D}\right) \frac{b^{2}-a^{2}}{b^{2}+a^{2}}}{\frac{a}{D}+\lambda\left(1+\frac{a}{D}\right) \frac{b^{2}-a^{2}}{b^{2}+a^{2}}}
\end{aligned}
$$

where $U^{\prime}(r)$ represents the first derivative of $U(r)$ with respect to $r$. Radial distribution of flow velocity $V(r)$ is plotted against logalithmic the distance in Fig. 7. Emf profiles at $V_{\text {mi }}$ of 0.95 $\mathrm{m} \mathrm{s}^{-1}$ and those at $V_{\mathrm{m}}$ of $0.63 \mathrm{~m} \mathrm{~s}^{-1}$ appear comparatively well fitted with straight lines in parallel. On the other hand, profiles at $V_{\mathrm{m}}$ of 0.32 $\mathrm{m} \mathrm{s}^{-1}$ seem to be curved and is not parallel to the others. It is considered on the basis of Fig. 6 and 7 that turbulent core is not fully developed at the mean velocity of $0.32 \mathrm{~m} \mathrm{~s}^{-1}$, which corresponds to the Reynolds number of 7.19 $\times 10^{3}$. Effect of the magnetic field on the flow, which is expected in the case of the largest Stuart number $\mathrm{N}$ in Table 1 , was not observed. Such an effect would be smaller than random

$$
V_{\mathrm{m}} / \mathrm{m} \mathrm{s}^{-1}
$$

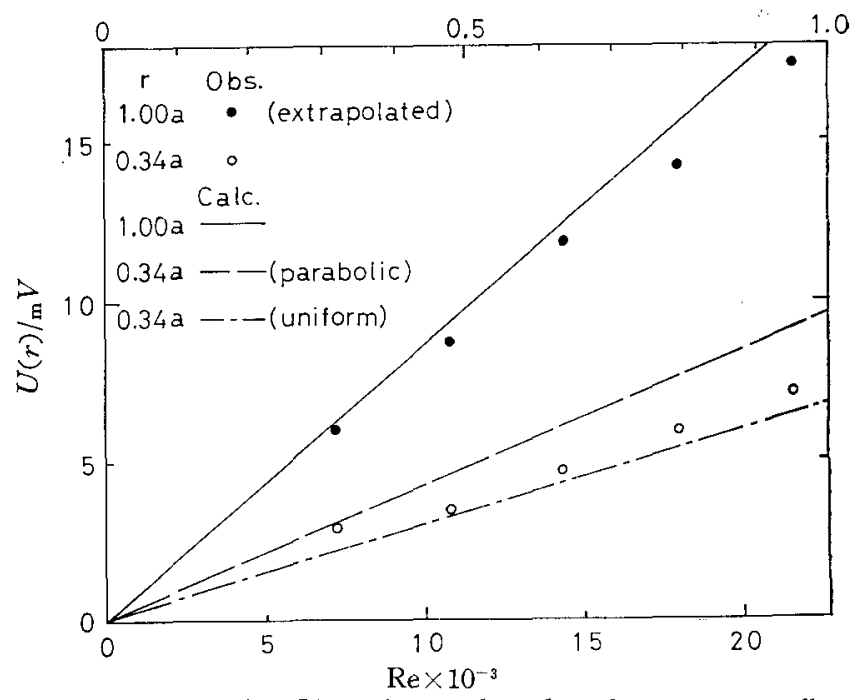

Fig. 6 Potentials $U(r)$ observed under the magnetic flux density of $0.72 T$ at different radii $r$ in the pipe and those calculated from the mean velocity $V_{m}$ of the flow at the corresponding radii and the magnetic flux density by making assumptions on the velocity profiles, i.e. parabolic one and uniform one, are plotted against the Reynolds number $\mathrm{Re}$ and against the corresponding mean velocity $V_{\mathrm{m}}$ together, where ' $a$ ' denotes the inside radius of the pipe 


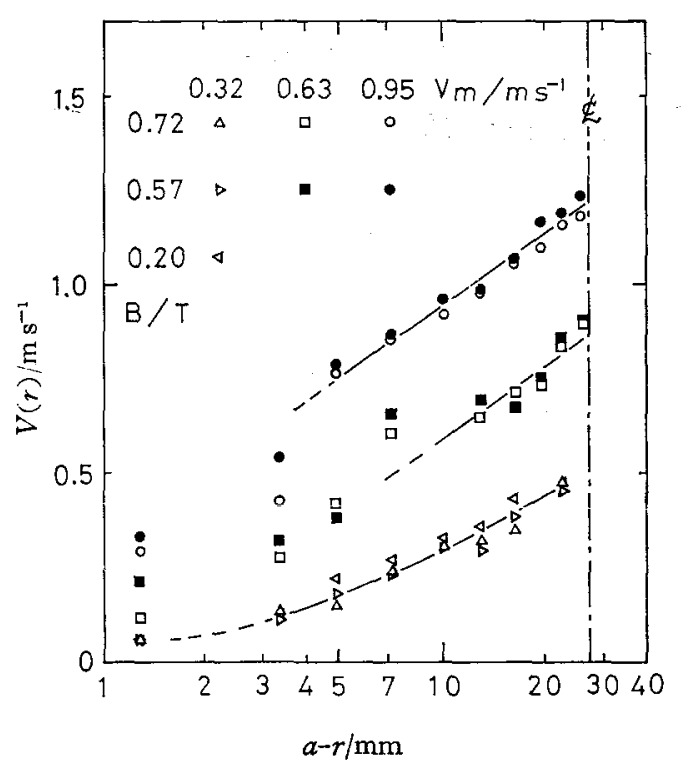

Fig. 7 Velocity profiles $V(r)$ calculated from observed potentials at different mean velocities $V_{\mathrm{m}}$ are plotted by regarding the imposed magnetic flux density $B$ as a parameter against the distance from the pipe wall $(a-r)$ on the logarithmic scale, where ' $a$ ' denotes the inside radius of the pipe

error in Fig. 7 if it were.

\section{Concluding Remarks}

It was confirmed that induced emf in the molten-salt flow can be measured by using the method in this work. Observed emf's indicate that the formation of turbulent core increases with increase of the Reynolds number. Little hydrodynamical effect of the magnetic field on the molten-salt flow was confirmed under the condition at the maximum Stuart number of $5.34 \times 10^{-4}$

\section{Acknowledgement :}

The authers are indebted to Professor Hiroshi Mitachi of Toyohashi University of Technology for providing the facility to calibrate the flowmeter and for his helpful advice. We also wish to thank $\mathrm{Mr}$. Kikuo Kimura of Japan Atomic Energy Research Institute for his hearty assistance in fabricating the glass sealed probes. Financial support of Grant-in-Aid for fusion research No. 56050011 from Ministry of Education is greatly acknowledged.

\section{References :}

1) M.A. Hoffman and G.A. Carlson, UCRL-51010 (1971).

2) K. Furukawa, JAERI-M 6684 (1976).

3) G. Trommer, IPP 4/165 (1977).

4) W.R. Grimes and S. Cantor, "The Chemistry of Fusion Technology", Plenumpress, New YorkLondon, 161 (1972).

5) M. Faraday, Phil. Trans. Roy. Soc., Part 1, 163 (1832).

6) B. Thürlemann, Helv. Phys. Acta 14, 383 (1941).

7) A. Kolin, J. Appl. Phys. 15, 150 (1944).

8) H.G. Elrod Jr. and R.R. Fouse, Trans. ASME 19 , 589 (1952).

9) J.A. Shercliff, AERE X/R 1052 (1952).

10) W.E. Kirst, W.M. Nagle and J.B. Castner, Am. Inst. Chem. Eng. Symp. Ser. 36, 371 (1940).

11) Y. Uchiyama and K. Kawamura, J. Chem. Eng. Data 26, 407 (1981).

12) P.G. Gaune, J. Chem. Eng. Data 27, 151 (1982).

13) "O.J. Foust (ed), Liquid Metals Handbook, Sodium and NaK Supplement", U.S. Govt. Print. Off., Washington, 4.73 (1967).

14) A. Nishikata, H. Numata and S. Haruyama, Nippon Kinzoku Gakkai-shi 45, 610 (1981).

(Received Oct. 29, 1982 ; Accepted Dec. 16, 1982)

\section{半玄体電極と光触媒・文献集 1981 年 10 月版}

電気化学協会光電気化学研究懇竸会編 B 5 判 125 ページ 頒布価 2,000 中 (送料共)

败現在 半導体電極や光触媒の研究が世界的に活発で, 研究の流れの速いのに目をみはるものがあります。発表される論文数も相当 な数にのぼります，今回，多くの専門家の協力によってこの方面の文献を 1981 年夏をでの時点で，をめて抄録しました。1人 1 人の研究者では文献を集め, まとわるのは大变な時間之労力を要します.

々今回の文献集は, Gerische, Bard らの論文を始め, ソ連, 中国などの研究も含めて一つ一つ抄録されており，全部で 300 以上の 光電気化学に関する最新論文が研究者ごとにまとめられて集められています。

現在, 光電気化学にたずさわっておられる方々も, また, これからこの方面の研究を始めようと考えて抢られる人達にむ非常に 役立つ一册と考えられます. 多数の力ネのご利用をお待ちします.

汉申込先 100 東京都千代田区有楽町 1-12-1 新有楽町ビル 電気化学協会光電気化学研究懇談会 (83-214-6001). 